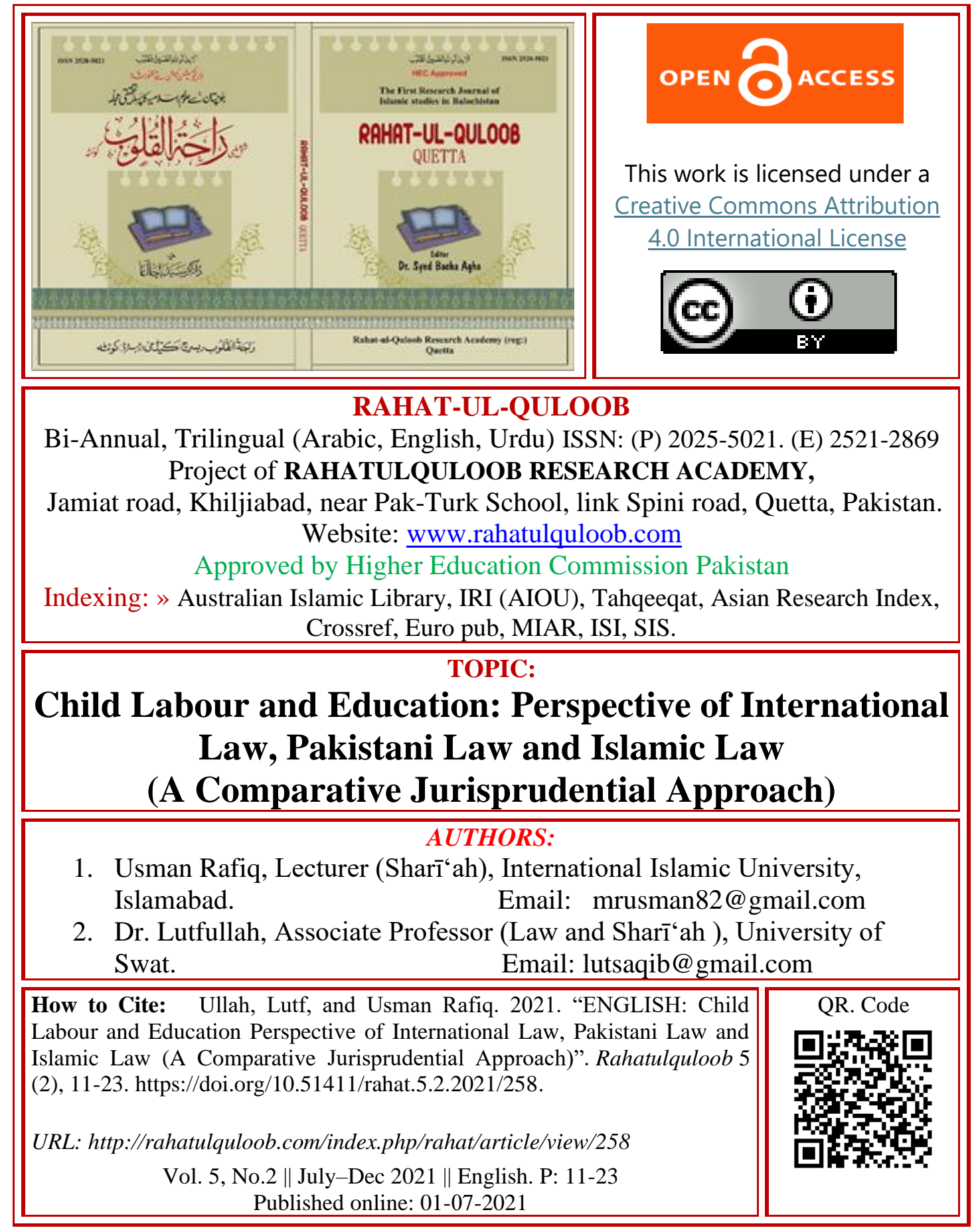




\section{Child Labour and Education: Perspective of International Law, Pakistani Law and Islamic Law (A Comparative Jurisprudential Approach)}

${ }^{1}$ Usman Rafiq, ${ }^{2}$ Lutfullah

\section{ABSTRACT:}

Education, of course, is allied with the child labour; where the increase of one is the decrease of other. Both, education and protection from child labour, are the basic rights of all children without any sort of discrimination. Contemporary literature shows drastic increase in child labour all over the world. All this is even in the presence of international conventions regarding child rights, specifically, the UNCRC 1989 - a legal document globally ratified. Owing to this fact, the international law, related to children rights, faces threat in this regard. Islamic Law, on the other hand, too, provides a comprehensive legal mechanism and structure for children rights. Comparatively to other legal spectrum, Islamic law is more effective in term of its jurisprudential approach to children rights. Pakistan, being an Islamic country, remained under the administrative control of the Great Britain and, therefore, follow a plural law - a mixture of Islamic and conventional law. This study, thus, probes the International Law, Islamic Law and Pakistani Law in connection to child education and child labour. Finding shows, with solid evidences, that Islamic law offers a comprehensive mechanism for children rights - protecting these both at strategic and operational levels. Content analysis technique, being an important research tool of qualitative method, has been followed for the investigation of the issue.

Keywords: Child Rights, Child Labour, UNCRC 1989, Islamic Law, Pakistani Law.

\section{Introduction:}

Human wisdom, of course, cannot deny the importance of education-under any stretch of explanation; specifically for children who are considered assets for nations' future. ${ }^{1}$ It is not only a right rather it authorizes to get all the remaining rights coming under its ambit. ${ }^{2}$ Through this very right, children can be fully equipped for their lives in their communities; with accord to dignity and equality. It is the education that develops children, appropriately, and builds up, at the same time, their mental, social and physical capabilities-the indispensable qualities of dynamic nations. ${ }^{3}$ Moreover, it can contribute to enlighten their lives and bar the poverty cycle for their better times.

Early childhood, in the view of scholars, is very important time for their physical and mental health abilities. The children grow up, according to these scholars, faster till five years of age. ${ }^{4}$ Owing to this fact, Early Childhood Education is very important time; whereby many benefits can be secured by the children. Here, at this point, they may be versed with a better training and education. However, the global challenges like poverty, fraud, natural disasters, increased discrimination and political interventions affected, very badly, their education and enhanced, by the same way, their labour. ${ }^{5}$ The child labour, in case of Pakistan, is deeply rooted. Child labour, herein, is 
considered one of the worst forms of child exploitation. Children can easily be seen working in economic zones of the country. Some of occupations, available in these economic zones, are very much risky in their nature. ${ }^{6}$ Agriculture, mining coal and salt, brick making, forced labour, carpet industries and tanning, can be cited as few examples. ${ }^{7}$ As per Human Right Commission of Pakistan report, there are ten million children who are connected with labour - by one way or another. ${ }^{8}$

Islamic Law, being a comprehensive legal mechanism, focuses on the education of children from the start of childhood through the mothers followed by teachers and scholars. Moreover, labour and abuse are far away, Islam encourages being compassion with the children from the start of their childhood. Because of this reason Islam is considered more idealistic and favorable for the children rights.

Keeping children away from education and pushing them towards child labor is like depriving them of their rights. The objective of this study is to analyze this issue and find an appropriate solution. Moreover, few questions must be probed in this regard. For instance, the stance and method of ongoing International Law is better or that of Islamic Law? What are the bases that help International Law and Islamic Law in this regard? What are the punishments discussed by both these legal system for discouraging child labour? Finally, where the Pakistan Law stands in all these situations?

\section{Education vs Child Labour; An Interlinked Concepts:}

Child labor cannot be explained in simple words as it has very complex dimensions both at theoretical and practical levels. In many cases, for instance, child related issues, like poverty and other family problems, make him as laborer to support his family. Likewise, the cultural relativism cannot be ignored, too, in respect of education and child labor. Moreover, the national economic situations also play a role in this connection. Because of these reasons, and many others, child lablour becomes a complex issue. Education and child labor, as mentioned previously, are interwoven. Education is, possibly, the basic component that bars the child labour. The child labour, on the same way, also works as a basic barrier in attaining education. Because of this, those children who cannot enter into education opt child labour and, thus, put themselves in risky works and abusive environments. Additionally, children working around the clock, of course, cannot get education. It happens many times that children who combine their work and education, after some span of time, leave the school by entering into full time work. ${ }^{9}$ While discussing this relation of education and child labour Benita Ferrero-Waldner ${ }^{10}$ states $^{11}$

"I am pleased that this year the day is dedicated to raise awareness of the importance of education in fighting child labour. I am convinced that improving access of all children to education is the right response to this evil. Fight against child labour is for me a core commitment in our human rights agenda and I will continue to raise it in my political dialogue with other countries." 12

The above statement clarifies that child labour not only affects child's education but, at the same time, jeopardizes his safety, health and development, too, ${ }^{13}$ The children, 
as per some scholars, also become socially and financially unprotected. Education, indeed, is an important factor for eradication of child labor. Child work not only stops the facilities of skills acquiring, training and schooling, but it also sustains poverty at national level. ${ }^{14}$ Countries, primarily, the developing ones where the education appears to be a huge problem, their people are oftenly, engaged to earn the livelihood. In such countries, parents give priority to childhood earning rather than education.

\section{Forms and Roots of child labor in Pakistan: A Reality or an Illusion:}

Children work, usually, under the apprenticeship under their parents. Some of them help parents in chores and other in business. There are, of course, others who work in part times for supporting their families along with schooling. Then, some children are involved in full time work, for instance, selling and buying. The most dangerous child labour, however, is when they are exploited in a risky and dangerous work - a situation where their basic rights are infringed. The children, here, feel depressed and more often mentally retarded. In a recent guesstimate, annually twenty-two thousand children defeat their lives in their work. ${ }^{15}$ Sometimes, the risk in the child labour switches towards very dangerous immoral activities where they are pushed forth in prohibited activities e.g., sexual activities. All rights of children, in such a situation, have subjected to severe violation. According to an authentic report, two hundred and eighteen million children are employed globally between five to seventeen years of age. Among these, one hundred and fifty-two million are facing child labour while seventy-three million are engaged in hazardous and risky child labour! Furthermore, this hazardous work prevails from ages fifteen to seventeen years. Amongst one hundred and fifty-two million working children consist of eighty-eight million boys and sixty-four million girls. ${ }^{16}$

Scholars have different opinion regarding nature of the child labour. In view of some, all the above-mentioned kinds are considered to be child labour. Contrary to this, others consider only the hazardous work is the child labour. The latter opinion seems to be more appropriate comparatively to the previous one; as the hazard work makes the children vulnerable towards their education. In addition, the children, in this situation, become blind about their future and development. Other types of child labour, contrary to this, do not interfere with their education. Moreover, the International Labour Organization ILO $182^{17}$ and Convention on the Rights of the Child $1989^{18}$ have the same opinion. While having the above discussion in mind, the child labour can be categorized into two kinds. First is bonded child labour. Here, the child starts working as he is under liability to pay a certain sum amount as debt to his employer. It happens when the family members of a child take loan from his employer to fulfill his basic needs. The employer, in this case, employs the same child as labour and the due amount is deducted from his wages. This bonded child labor most rottenly grows up as the child has not only to pay the original amount but also the interest. The cycle, unfortunately, continues and the child transmits, ironically, the loan to his own children latter on the child, herein, in some worst cases becomes just like a slave. The children, 
in such cases, are put in darkened circumstances in their innocence age and, therefore, deprived from their rights like education and health. Furthermore, the risk in such type of labour depends on child's age. Agriculture, mine, brick kilns and domestic works, most commonly, maintains this type of labourship. ${ }^{19}$ The Second type is nonbonded child labour whereby the child is engaged in a work to seek food, shelter for himself or his family or to help out his father in fulfilling basic needs. ${ }^{20}$ It is immaterial for him/ her whether these works are risky and hazardous in their nature or otherwise. The child, in this type of labour, is under no liability or burden to pay any amount as debt to his employer.

\section{Activities contribute to promote Child Labor:}

Astonishingly, some of the people support for child labor due to poverty in a society but they don't realize, for one reason or another, that the child labor is the central reason for poverty. ${ }^{21}$ There are many reasons for such child labour. Firstly, the employers want cheaper, respectful and obedient labours - those who can work without any complain. They feel, though wrongly, that children are fit for all these purposes. Moreover, sometimes they do not compensate children's injuries or disabilities in course of their work. Also, the children, being less educated or illiterate at all, are paid less than adult. All these go in favour of employers and, therefore, they prefer children for labourship. Due to low income, head of the family and his children are forced to do work owing to the fact that adult cannot find sufficient earning to manage his family's needs. This indeed, restrains the children from education; as they, being labour, cannot even think about the schooling, training or skill acquiring. ${ }^{22}$

Neglecting and abuse behavior of parents, too, may contribute in this regard. Report on Violence and Health observes the same fact. ${ }^{23}$ According to this report, some parents do not care for their children's care and education. Personal interest of children, sometime, causes child labour where they are in need of money for their lively-hood. ${ }^{24}$ Another possible cause for the child labour is bonded labour where the children open their eyes in the darkness of the child labourship. Same is the situation where the children are trafficked internally or cross borders.

\section{Child Labour and Education- Perspective of International Law: UNCRC on Education:}

$\mathrm{UNCRC}^{25}$, an important document of international law, devotes its Article No. 28 to the education. The CRC has an immense concerned about the education. It suggests, for instance, making educational information to all people so they may feel free to contact the educational institution. Likewise, it encourages international support and cooperation to depart the ignorance. ${ }^{26}$ As far as the primary education is concerned, it recommends by making it compulsory and free for all; meaning thereby that all costs of primary education should be borne by the state. The document (UNCRC) furthers says that the state has to ensure secondary education i.e., general, vocational, technical and scientific education, accessible and offered to all the children without any sort of discrimination. ${ }^{27}$ It further suggests financial assistance to the needy children. ${ }^{28}$ The 
same approach is made by the document for the higher education. ${ }^{29}$ The financial assistance, however, is not offered, herein.

\section{UNCRC and Child Labor:}

UNCRC Article 32 commits to protect children from the evil of child labor. It goes on the prevention of any work that is hazardous and risky towards education and other rights of the child. ${ }^{30}$ Its emphasis the state to legislate various laws related to children's rights i.e., the minimum age for the work, working conditions, working hours and etc. In addition, in case of violation of these rules, sentences should also be provided by the states. ${ }^{31}$ It is pertinent to mention, herein, that training and apprenticeship are not the child labor within the meaning of UNCRC.

\section{ILO on Child Labour:}

ILO Convention $(\mathrm{C} 138)^{32}$ takes the same position as that of UNCRC. It also prohibits, for instance, any kind of work that endangers safety, health or morals of the children, primarily, those who are under the age of eighteen years. ${ }^{33}$ Owing to this fact, a light work is, though, allowed from the age of thirteen to fifteen. By light work, herein, means a work that is not injurious for children's health. ${ }^{34}$ It further says that educational institutions (schools) have no liability for any work done in the course of education or training. ${ }^{35}$ ILO convention $(\mathrm{C} 182)^{36}$ goes on saying that the state parties are having the duty to take immediate measures to combat child labour as soon as possible. ${ }^{37}$ As per this legal document, slavery practice, debt bondage and forced child labour are the worst forms of child labour. ${ }^{38}$ Identifying the importance of eliminating the worst forms of child labour, the Convention recommends free basic education and the rehabilitation for children and their families. ${ }^{39}$ Moreover, along with the free basic education, the vocational education and training should also be provided. ${ }^{40}$

Considering the role of poverty in child labour, the convention suggests that continued economic development may be made through social progress, especially, for universal education. ${ }^{41}$ It is easily understandable that these ambitions cannot be fulfilled by each state individually; rather there is a need for the collective team work. Increased international cooperation, therefore, is need of the time for the social and economic growth and poverty suppression; the base for child labour. ${ }^{42}$

\section{Pakistani Law's Approach towards Child Labour and Child Education:}

As per the constitution of Pakistan ${ }^{43}$, education as compulsory for the entire citizen without any sort of discrimination on the basis of clour, creed, religion, sect and etc. It suggests hard work to eradicate illiteracy by promoting and providing free and compulsory education. ${ }^{44}$ Also, it forbids the child labor and the forced labor under the age of fourteen. ${ }^{45}$ Keeping in view the task of education to combat the child labor, the Constitution requires the state to take full responsibility of children's education from age five to sixteen; through free and compulsory education. ${ }^{46}$ It is very key to mention, herein, that Pakistan's National Education Policy, 2017 has declared, firmly, education as a fundamental right of children. As per this document, primary education would be universalized for boys till 2020 and for girls till 2025. ${ }^{47}$ Moreover, the state should 
ensure that no one among the children or women is employed in a work inappropriate with their age or sex. ${ }^{48}$ A close look at Pakistani law confirms the contradiction of its inner rules. The constitution after $18^{\text {th }}$ amendment, for instance, suggests compulsory education from five to sixteen years of age. The labor laws, on the other hand, declare the minimum age for work 14 years. On the same way, some provincial laws are also differing from each other on the same issue. The Employment of Children Act, 1991, for example, fixes fourteen years of age as the minimum age for the employment of children. ${ }^{49}$ However, it is allowed, ironically, for a child of less than fourteen years to work with the help of his family. ${ }^{50}$ The reason it's being a type of training or apprenticeship of the family expertise.

In Punjab, the minimum age for employment is fifteen; meaning thereby that a child cannot be employed while being child. ${ }^{51}$ As for the adolescent ${ }^{52}$ his work is allowed subject to the condition if does not clash with the timings of his educational or vocational institutions. ${ }^{53}$ But, even the adolescent, cannot be employed in hazardous work that harm his health, safety and morals. ${ }^{54}$ It means that the hazardous work is permitted for the adulthood which starts from eighteen years of age. In Sindh, the minimum age for the work is fixed as fourteen. ${ }^{55}$ The hazardous work is disallowed for the adolescent; the children having age from fourteen to eighteen. ${ }^{56}$ Moreover, children and adolescent's educational documents should be made ready by the occupier ${ }^{57}$ for the inspection of the competent authority. ${ }^{58}$ In Khyber Pakhtunkhwa, the minimum age for the employment is fourteen years, too. ${ }^{59}$ No child, according to this legal document, is allowed to do labour. The child of twelve years of age, however, may keep a light work in the company of his family members. This would be, however, only for two hours daily to get skills. ${ }^{60}$ For adolescent, the same rules are applicable, herein, as that in Sindh province. ${ }^{61}$ So, the differences among the province's laws are clear.

Contradiction exists, in the contemporary laws, in the penalties which are inflicted on the culprits who violate the minimum age for employment. They are imprisoned, for instance, for one year or with a fine Rs. 20,000 or with both. ${ }^{62}$ However, as per other legal documents of Khyber Pakhtunkhwa and Sindh, such culprits are liable to six months imprisonment or with a fine (up to Rs.50, 000) or with both. Moreover, when the work is hazardous, then the punishment may go to three years along with fine upto Rs.100, 000. But the pecuniary punishment should not less than Rs.10, 000. For adolescent, the employer is subject to punishment to the extent of one year or with a fine up to Rs.75, 000 or with both. ${ }^{63}$ In Punjab, on the other hand, the culprit is liable to imprisonment from seven days to six months and with a fine starting from Rs. 10,000 to Rs. 50,000. The employer in the Hazardous ${ }^{64}$ work, however, is punished with three to seven years and with a fine from Rs. 200,000 to Rs. $1000000 .{ }^{65}$ All this discussion clearly indicates that each provincial law has a diverse opinion. Moreover, some provinces have discussed the issue of hazardous work while the other left the same intentionally or unintentionally. Equally, some of them have discussed the issue of the education, vocational training and skill while other legal documents do not have 
a single glance over it. The penalty clauses, in various provincial documents, have, too, inner contradiction. A strict scrutiny of all these laws favors the fact that the Punjab Law is comparatively comprehensive and better.

In Pakistan, there are some other related laws but they are not properly implemented owing to some obstacles. The issue of poverty, for instance, comes first to infringe children right to education. They do not know whether to educate themselves or to earn something for their livelihood and this isolation between two positions put them in forever troubles. Secondly, some people think, though wrongly, that the business and work is better than the education entrepreneurship is better than education. They prefer, because of this reason, the business instead of education, mainly, when they see the degree holders are free by getting no jobs. ${ }^{66}$ The government of Pakistan has taken many measures to avoid child labour and its reasons to the last possible extent. Many of these measures are taken in coordination with national and international NGOs. The Federal Bureau of Statistics with collaboration of ILO, for instance, have conducted various surveys; showing that 3.36 million children are engaged in child labour having age from the five to fourteen years. ${ }^{67}$ School for Rehabilitation of Child Labour, working under Pakistan Bait-ul-Mal, can be cited a best example showing efforts of the government. At such schools, children are also given what they need. Moreover, subsistence allowance is given to parents of the registered children, too. This school, nowadays, has one hundred and fifty-nine centers all over Pakistan. ${ }^{68}$

\section{Child Labour and Child Education - A Realistic Position of Islamic Law:}

The first word of the Holy Qur'ān declares a right to education as a fundamental right for all. This right has been confirmed not as option but obligation. So, as the first instance, it is the duty of parents to educate their offspring what is necessary for them. In Islamic law, the term "education" does not mean religious education rather it means all form of education e.g., religious, technical, vocational, scientific etc. Following are some verses of Holy Qur'ān and Ahādīth of the Holy Prophet (SAW) as evidences of these facts: ${ }^{69 "(ق ر ا ٔ ب س ~ ر ب ك ~ ا ل ذ ي ~}$

"Proclaim! (Read!) in the name of the Lord and Cherisher, who created."70

"طلب العلم فريضة على كلمسلم."71"."Quest of knowledge is obligation upon every Muslim."

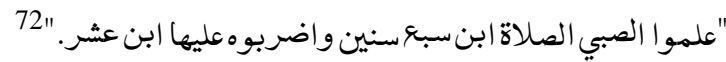

"Teach the minor to pray when he is of seven years, and beat him - if he does not pray - when he is of ten years."

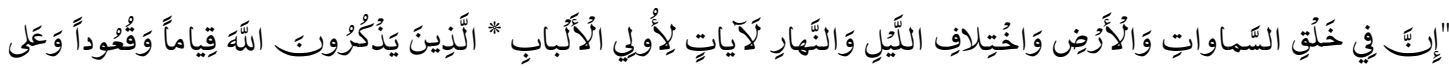

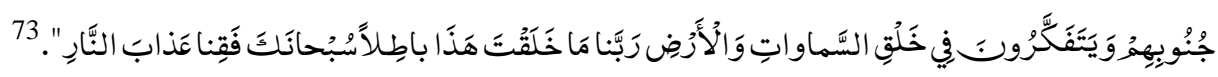

"Behold! In the creation of the heavens and the earth, and the alternation of night and day, - there are indeed Signs for men of understanding. men who celebrate the praises of Allah, standing, sitting, and lying down on their sides, and contemplate the 
(wonders of) creation in the heavens and the earth, (with the thought): "Our Lord! not for naught hast Thou created (all) this! glory to Thee! give us salvation from the penalty of the Fire". ${ }^{74}$

The word 'iqra' in the first verse is an imperative which tells us obligation to read. The second is clear evidence that seeking knowledge is the duty of every Muslim. The third tells us to fulfill our duty by teaching our children. As for the fourth verse of Holy Qur'ann, it tells us that education is not the religious one but it contents nonreligious education as well; as deliberation in the creation is not possible only be the religious education. Even otherwise, the deliberation helps for the remembrance of Allah Almighty. The child labour, as discussed earlier, is always subject to customs, traditions and situations of a particular area. Because of this reason, applying the same rules is not possible for each area. The Islamic principle of public interest i.e., Mașlaḥa, herein, comes to decide whether child labour, in a particular area, should be allowed or not. A strict jurisprudential approach should be made at this point for the solution of some questions. For instance, whether the child is in need to earn for himself or not? What is the financial status of his guardian? and etc. The $\mathrm{CFI}^{75}$, an international Islamic legal instrument, stresses on free primary education. ${ }^{76}$ The $\mathrm{CRCI}^{77}$, another inter-national legal document, suggests that the secondary education (of children) should also be made compulsory and free. ${ }^{78} \mathrm{DRCCI}^{79}$ has the same opinion. ${ }^{80}$ Further, CRCI prohibits the risky works for the children i.e., those which jeopardize their education or health. On the same way, it proposes that legislation should be made by the state's parties regarding the minimum age of work, work hours, conditions and etc. Also, the punishments should be decided for an individual who violates such laws. ${ }^{81}$ The mosque always remains a central place for educational and political activities. The madrasah ${ }^{82}$, being an integral part of mosque, too, plays a crucial role in educating children, adolescents and adults of the society. The reason is that a madrasah does not need high expenditures and infrastructures. For example, the children do not need separate buildings, individual chairs and tables to study; they may sit on the floor for their education. Moreover, it does not put any financial burden neither on parents nor on state. For educating children, some of the Muslim jurists have suggested a comprehensive mechanism and structure; describe a particular type of education at a particular time. ${ }^{83}$ Study shows that majority of classical Muslim jurists and scholars have got high level of education in their childhood. For example, Imam Shafi ${ }^{-84}{ }^{84}$ has completed hif ${ }^{85}$ of Holy Qur'ān in seven years and memorized, too, al-Muwatta' in his ten years. ${ }^{86}$ Another example is a great Muslim Jabir bin Hayyan ${ }^{87}$ who was considered Father of chemistry, medicine, astrology, philosophy and mysticism at the same time. ${ }^{88}$ Definitely, this was due to study he had begun in his childhood.

\section{Child Education and Prevention of Child Labour; Challenges in Pakistan}

Pakistan faces troubled economy and, therefore, economic instability. Increase in poverty restricts government's capability to educate all its citizens, primarily, children. Owing to this fact, most of the children in Pakistan are having no access to basic primary 
education. Here at this situation, child labour gives birth.Education has got worldwide recognition as a basic human right, predominantly, after the UNCRC, 1989. In spite of these international efforts, children are still not going to schools. This situation, of course, leads to child labour - and this later sometimes destroys a child's life. There is a dire need to accord child friendly national legislation in accordance with the UNCRC, 1989. For this purpose, concrete consideration should be given by both federal and provincial authorities; shaping plans and policies with regard to all children without any sort of discrimination. These demands, of course, strong a political will on the part of the state. There are ten million children deprived of education ${ }^{89}$. Majority of these are engaged in labour by one way or another. The future generation would be productive when they are empowered through education and training.

\section{Conclusions and Recommendations:}

Children are human beings. They have certain rights and duties as discussed earlier. Moreover, it is in benefit of all nations to consider them as such. In this regard, the states should legislate appropriate laws for child's education and protecting him, at the same time, from labour. Moreover, amendments should be made in the existing laws; making them children's friendly. While following this, the state has to act positively through the provision of free education and elimination of child labour. Likewise, it is also duty of the state to observe the child labour keeping in view the bonded and forced labour and to appoint also inspector to that effect. As a matter of fact, child labour can be eliminated through effective education and because of this reason primary free education is made a compulsory part for every policy related to children. ${ }^{90}$ A possible technical help can be taken from International Programmed on the Elimination of Child Labour (IPEC) as it offers the same. Investment in education, indeed, should be a way to eliminate child labour to the last possible extent. In addition, new training programs for children and their teachers are the key elements to promote children's education. On the same way free, compulsory and good quality education would also help in achieving the intended objectives. Further, evening school may also prove vital, primarily, for those engaged in apprenticeship under their parents. In this connection, rural areas of the country should be focused more comparatively to the urban one; as the previous have high illiteracy rate.

\section{References:}

${ }^{1}$ Idrisa, Fazilah, Zaharah Hassana, Azizah Ya'acoba, Saran Kaur Gillb and Noor Aziah Mohd Awal, "The role of education in shaping youth's national identity", Procedia - Social and Behavioral Sciences, 59 (2012). See for further details https://core.ac.uk/download/pdf/81145809.pdf. (Accessed $24^{\text {th }}$ June, 2020)

2 "Right to Education", Theirworld, accessed on July 16, 2020, https://theirworld.org/explainers/rightto-education.

${ }^{3}$ Barry, Margaret, Aleisha Mary Clarke and Katherine Dowling, "Promoting social and emotional wellbeing in schools", Health Education, Vol. 117, Issue: 5 (June 2017), pp. 435-436, see for further details https://www.researchgate.net/publication/317834703_Promoting_social_and_emotional_well-being_ 
in_schools. (Accessed 22 $2^{\text {nd }}$ March, 2020)

${ }^{4}$ U.S. Education Department, Washington, 2005, Physical and Mental Well-Being. Accessed May 31, 2020. see for further details https://www.readingrockets.org/article/physical-and-mental-well-being.

${ }^{5}$ F.A. Ajagbe and D.O. Adegbite, "Impact of Child Labor on Child Education in Ogbomoso," Global Journal of Commerce and Management Perspective, vol. 3 (4), 2014. see for further details https://www.longdom.org/articles/impact-of-child-labor-on-child-education-in-ogbomoso-area-of-oyostate-nigeria.pdf. (Accessed 20 $0^{\text {th }}$ April, 2020)

${ }^{6}$ Sadruddin, Munir Moosa, "Study on the Important Issues of Child Rights in Pakistan," The Dialogue, volume VI, number 1: 24.

${ }^{7}$ Malik, Nadeem, "Bonded Labour in Pakistan", Advances in Anthropology, Volume 6, Issue 4 (2016): 128. https://www.scirp.org/journal/PaperInforCitation.aspx?PaperID=72311.

${ }^{8}$ Rahim, Shahista, 2018. "Child Labour in Pakistan." The Nation, October 31. see for further details https://nation.com.pk/31-Oct-2018/child-labour-in-

pakistan\#: :text=Human\%20right\%20commission\%20Pakistan\%20estimated,in\%20Pakistan\%20occur s\%20in\%20agriculture. (Accessed 24th June, 2020)

${ }^{9}$ see for further details https://www.ilo.org/ipec/Action/Education/ChildlabourandEducationforAll/lang-en/index.htm. 22-10-2019. (Accessed 24 ${ }^{\text {th }}$ June, 2020)

${ }^{10} \mathrm{He}$ is EU Commissioner for External Relations and Neighbourhood Policy.

${ }^{11}$ Celebrated by the European Commission on June 12, 2008.

$12 \mathrm{https} / / /$ ec.europa.eu/commission/presscorner/detail/en/IP_08_926. Last visited on 29-11-2019.

${ }^{13}$ Paola Roggero, Viviana Mangiaterra, Flavia Bustreo and Furio Rosati, "The Health Impact of Child Labor in Developing Countries: Evidence From Cross-Country Data", American Journal of Public Health, vol. 97 (2), 2007. see for further details

https://www.researchgate.net/publication/6605674_The_Health_Impact_of_Child_Labor_in_Developi ng_Countries_Evidence_From_Cross-Country_Data. (Accessed 12 ${ }^{\text {th }}$ April, 2020)

${ }^{14}$ International Labour Conference, working out of Poverty (Geneva: International Labour Conference, 2003), 10. see for further details https://www.ilo.org/wcmsp5/groups/public/---dgreports/---dcomm/--publ/documents/publication/kd00116.pdf. (Accessed 17 $7^{\text {th }}$ April, 2020)

15 "Hazardous child labour", International Labour Organization, accessed June 21, 2020, https://www.ilo.org/ipec/facts/WorstFormsofChildLabour/Hazardouschildlabour/lang--en/index.htm.

16 "Child Labour", International Labour Organization, accessed June 21, 2020, see for further details https://www.ilo.org/global/topics/child-labour/lang--en/index.htm. (Accessed 17 ${ }^{\text {th }}$ April, 2020)

17 Convention concerning the Prohibition and Immediate Action for the Elimination of the Worst Forms of Child Labour (ILO 182). Article 3.

${ }^{18}$ CRC. Article 32 (1).

19 Devasitham M. and Premraj, Carter, "Bonded Labour System: Prevalence and Tackling", Indian Journal of Applied Research, vol. 4, issue 12 (Dec 2014). https://www.worldwidejournals.com/indianjournal-of-applied-research-(IJAR)/special_issues_pdf/December_2014_1418821165_29.pdf.

20 "What is Child Labour", International Labour Organization, accessed on July 17, 2020. see for further details https://www.ilo.org/ipec/facts/lang--en/index.htm(accessed $8^{\text {th }}$ June, 2020)

${ }^{21}$ Sasmal, Joydeb and Guillen, Jorge, "Poverty, Educational Failure and the Child-Labour Trap: The Indian Experience", Global Business Review, Volume 16, issue 2 (April 2015): 270, see for further details https://doi.org/10.1177/0972150914564419. (Accessed $15^{\text {th }}$ May, 2020)

${ }^{22}$ Ibid.

${ }^{23}$ World Report on Violence and Health, Child Abuse and Neglect by Parents and other Caregivers (Geneva: World Health Organization, 2002), p. 60.

${ }^{24}$ Haider, Syed Zubair and Ayesha, Qureshi, "Are All Children Equal? Causative Factors of Child Labour in Selected Districts of South Punjab, Pakistan”, New Approaches in Educational Research, 
Vol. 5, No. 1 (January 2016), p. 3.

${ }^{25}$ United Nations Convention on the Rights of the Child 1989. This convention has been created to state all rights of the children in the history after Islamic Law. It covers every child whatever was their gender, religion, language or any other status. They are human beings, so, they have all the civil, social, cultural and political rights. Another thing makes the difference is that the UNCRC has been ratified by all the countries except United States of America.

${ }^{26}$ UNCRC. Article 28 (1-d) and 3.

27 "A Human Rights-Based Approach to Education for all”, United Nations International Children's Fund, accessed July 05, 2020,

https://www.unicef.org/publications/files/A_Human_Rights_Based_Approach_to_Education_for_All.p df.

${ }^{28}$ UNCRC. Article 28 (1-b).

${ }^{29}$ UNCRC. Article 28 (1-c).

${ }^{30}$ UNCRC. Article 32 (1).

${ }^{31}$ UNCRC. Article 32 (2).

32 The ILO Convention concerning Minimum Age for Admission to Employment (C138). [Hereinafter referred to as C138].

${ }^{33}$ C138. Article 3(1).

${ }^{34}$ C138. Article 7(1).

${ }^{35}$ C138. Article 6(a).

36 The ILO Convention concerning the Prohibition and Immediate Action for the Elimination of the Worst Forms of Child Labour (C182). [Hereinafter in referred to as C182].

${ }^{37}$ C182. Article 1.

${ }^{38} \mathrm{C} 182$. Article 3.

${ }^{39} \mathrm{C} 182$. Preamble, para 3.

${ }^{40}$ C182. Preamble, para 3, read with, Article 7(2).

${ }^{41}$ C182. Preamble, para 5.

${ }^{42}$ C182. Article 8 .

${ }^{43}$ The Constitution of Islamic Republic of Pakistan 1973. (Hereinafter referred to as The Constitution).

44 The Constitution. Article 37(a-b).

45 The Constitution. Article 11.

46 The Constitution. Article 25(A).

${ }^{47}$ National Education Policy 2017, p.48.

48 The Constitution. Article 37 (e).

${ }^{49}$ Employment of Children Act 1991. Section 2(iii).

${ }^{50}$ Employment of Children Act 1991. Section 3.

${ }^{51}$ Punjab Restriction on Employment of Children Act, 2016. Section 2(c) and 3(1).

52 The adolescent is from 15 to 18 years of age. See, Punjab Restriction on Employment of Children Act, 2016. Section 2(a).

${ }^{53}$ Punjab Restriction on Employment of Children Act, 2016. Section 5(3)(a).

${ }^{54}$ Punjab Restriction on Employment of Children Act, 2016. Section 3(2).

55 Sindh Prohibition of Employment of Children Act, 2017. Section 2(ii).

${ }^{56}$ Sindh Prohibition of Employment of Children Act, 2017. Section 3(2) and 2(i).

57 "Occupier" means "the person who employs workers either directly or indirectly". See Sindh Prohibition of Employment of Children Act, 2017. Section 2(xii).

${ }^{58}$ Sindh Prohibition of Employment of Children Act, 2017. Section 22(2).

${ }^{59}$ Khyber Pakhtunkhwa Prohibition of Employment of Children Act, 2015. Section 2(b).

${ }^{60}$ KPK Prohibition of Employment of Children Act, 2015. Section 3(1) along with its proviso. 
${ }^{61}$ Khyber Pakhtunkhwa Prohibition of Employment of Children Act, 2015. Section 3(2).

${ }^{62}$ Employment of Children Act, 1991. Section 14(1).

${ }^{63}$ Khyber Pakhtunkhwa Prohibition of Employment of Children Act, 2015. Section 15(1-2); Sindh Prohibition of Employment of Children Act, 2017. Sections 14(1) with proviso No. 1 and 14(2);

${ }^{64}$ Examples are mentioned in Punjab Restriction on Employment of Children Act, 2016. Section 11(3).

${ }^{65}$ Punjab Restriction on Employment of Children Act, 2016. Sections 11(1, 2, 3).

${ }^{66}$ Mirza, Faisal Mehmood, Atif Ali Jaffri and Muhammad Saim Hashmi, "An Assessment of Industrial Employment Skill Gaps Among University Graduates in The Gujrat-Sialkot-Gujranwala Industrial Cluster, Pakistan," The Pakistan Journal of Social Issues, Volume VIII (2017). https://uog.edu.pk/downloads/journal/PJSI_1-20.pdf. See also, Ameen Amjad khan, "Rising number of jobless $\mathrm{PhD}$ scholars causes concern," University World News, February 8, 2019, https://www.universityworldnews.com/post.php?story=20190208093402982.

67 Children's Complaint Office, Ombudsman and UNICEF, The State of Children in Pakistan, July 2015, p. 35-36. [hereinafter referred to as The State of Children in Pakistan].

68 see for further details http://www.pbm.gov.pk/ncrcl.html. Last visited on 15-12-2019. (Accessed 24th March, 2020)

${ }^{69}$ Al-Qur'ān $96 / 1$.

${ }^{70}$ Abdullah Yusuf Ali, Translator, The Holy Qur'ān with Arabic Text (Islamabad: Da'wah Academy, 2004), 1883. [Hereinafter referred to as The Holy Qur'ān with Arabic Text].

${ }^{71}$ Al-Bayhaqi, Shu'ab Al-Iiman, vol. 2 (Bayrut: Dar al-kutub Al-'ilmiyyah, 2000), 254, Hadith. 1665.

72 Al-Bayhaqi, Al-Sunan Al-Kubra, vol. 3 (Al-Riyad: Maktabah Al-Rushd, 2004), 122, Hadith 5191.

${ }^{73}$ Al-Qur'ān 3 / 190-191.

74 The Holy Qur'ān with Arabic Text, p. 199.

${ }^{75}$ Charter of the Family in Islam. (Hereinafter referred to as CFI).

${ }^{76}$ CFI. Article 114.

${ }^{77}$ Covenant on the Rights of t-he Child. (Hereinafter referred to as CRCI.

${ }^{78}$ CRCI. Article 12.

${ }^{79}$ Declaration on the Rights and Care of the Child in Islam. (Hereinafter referred to as DRCCI).

${ }^{80}$ DRCCI. Principle 8.

${ }^{81}$ CRCI. Article 18.

${ }^{82}$ Madrasa is a place of study in a mosque.

${ }^{83}$ See, Ibn Hazm, Rasail Ibn Hazm Al-Andalusi, Risalah Maratib Al-'ulum, edited by Dr. Ihsan Abbas (Bayrut: Al-Mu'assasah Al-'arabiyyah Liddirasat wa Nashr: 1983), p. 65-90.

${ }^{84} \mathrm{He}$ was one of the great jurists in Sharī'ah. He was born most correctly at Gaza in the year $150 \mathrm{AH}$ and died at Egypt in the year 204 AH. See, Șbāḥ Qāsim al-Imāmī, "Min sīrat al-Imām al-Shāfi ‘̄̄”, last modified July 12, 2020, https://www.saaid.net/bahoth/23.htm.

${ }^{85} \mathrm{It}$ is memorization of Holy Qur'ān.

${ }^{86}$ Al-Baghdādī, Abū Bakr al-Khațīb, Tarīkh Baghdād, v.2 Bayrūt: Dār al-Gharb al-Islāmī, 2002), p. 392

${ }^{87} \mathrm{He}$ was born at Khorasan, Iran in the year $721 \mathrm{AD}$ and died in the year $815 \mathrm{AD}$ in Kufa. See, Encyclopaedia Britannica, s.v. "Abū Mūsā Jābir ibn Hayyān”, accessed July 12, 2020, https://www.britannica.com/biography/Abu-Musa-Jabir-ibn-Hayyan.

${ }_{88}$ Amr, Samir and Abdelghani Tbakhi, "Arab and Muslim Physicians and Scholars: Jabir ibn Hayyan" Annals of Saudi medicine, 27(1), (January 2007).

https://www.researchgate.net/publication/45260574_Jabir_ibn_Hayyan.

${ }^{89}$ Children's Complaint Office, Ombudsman and UNICEF, The State of Children in Pakistan, July 2015 , p. 309.

$90 \mathrm{https} / / / \mathrm{www}$.ilo.org/ipec/Action/Education/ChildlabourandEducationforAll/lang--en/index.htm. 2210-2019. (Accessed 20 $0^{\text {th }}$ July, 2020) 